\title{
Evidence-based Smartphone Use among Engineering Students in an Academic Writing Course
}

\author{
https://doi.org/10.3991/ijet.v16i17.23949 \\ Jeffrey Dawala Wilang ${ }^{1}(\varpi)$, Michelle Andrino Garcia ${ }^{2}$ \\ ${ }^{1}$ Suranaree University of Technology, Nakhon Ratchasima, Thailand \\ ${ }^{2}$ King Mongkut's University of Technology, Bangkok, Thailand \\ wilangeg.sut.ac.th
}

\begin{abstract}
The role of smartphones is vital in academia as interconnectivity in the classroom promotes learning autonomy, increases motivation, and enhances teaching and learning mobility. Using classroom research design, this study aimed to investigate the perspectives of Engineering students of smartphone use in an academic writing course. The data were collected from students enrolled in a writing course in a top-ranked Science and Technology university in Thailand. Fifty students voluntarily submitted reflections towards the end of the semester. The study was qualitative, in which inductive coding was used. The findings elicited specific situations of smartphone use in an academic writing course, for example, knowing and looking at the meaning of words, knowing the word form, finding information, taking notes, brainstorming with friends, using translation, and others. Two roles of smartphone use were coded. The first role is facilitative, which has the following functions: resource-based, cognitive-based, memory-based, output-based, collaborative-based, entertainment-based, and communicative-based. Another is the debilitative role indicating two functions, such as sources of cognitive distraction and undesirable behaviors. Interestingly, self-regulation of smartphone use in class was coded. Implications on how smartphones can be used in teaching writing were also discussed.
\end{abstract}

Keywords - smartphones use, academic writing, reflective writings, facilitative role, debilitative role

\section{Introduction}

A growing body of research on smartphone use in the academe portrays its immense convenience for learning and teaching. It is used to access learning materials quickly, take notes or photos of slides, gain quick information about the topic at hand, ask for help from peers, enhance autonomous learning, etcetera. It is used to access academic information from cloud storage, manage class, send information to students, and create a more interactive learning environment. It is not surprising to find positive perceptions toward the use of smartphones in the classroom [1] [2] [3] [4] [5].

Providing affordances in learning, specifically smartphones, including various learning applications, give both the teachers and learners whole new learning experiences 
[6] [7] [8]. Kim and Kwon [9] reviewed a hundred smartphone applications that were designed for ESL learners. They reported that these applications provide personal and learner-centered learning opportunities and that learners can easily access language learning materials and tools at their convenience. Among teachers, due to the smartphones' portability and accessibility, many use them for learning and teaching purposes [10]. Other research pointed out that the use of smartphones can be used to leverage instruction [11, empower place-based learning [12], and amplify learning [13].

The use of smartphones in the classroom in the Thai context has been a significant issue whether students should be allowed or not to use their devices during class hours. Despite its advantages, its presence in the classroom is still inevitable that can cause distractions than as beneficial to learning. Such uncertainties prompted Yancey [14] to call for continuing research on emerging digital composing technologies. Using classroom research design, the teacher-researchers asked the students to freely write reflective writing to answer one question - What are the roles of smartphones in your writing course? The findings may provide a better understanding of how technology integration could affect the facets of writing pedagogies.

\section{$2 \quad$ Literature review}

Previous studies provided substantial evidence on how smartphone devices could be powerful learning support in language acquisition [13] [15] [16] [17]. Research has shown that smartphones are helpful learning tools - they can increase students' personal and academic interests and help students learn school subjects better [13]. Despite the convenience and helpfulness of smartphones in learning, some teachers seem to oppose seeing students using their smartphones during the lecture. Beland and Murphy [18] reported that some schools often prohibit its use in the classroom and the campus. Added to that, it is believed that using smartphones in the classroom is a distraction as people view mobile devices as entertainment rather than use them for educational purposes [19] [17]. Indeed, students use their smartphones for non-study purposes such as browsing on the internet, playing games on the application, chatting and posting on social networking sites, and shopping online during classes. As a result, a softwarebased intervention program was created to assist college students in self-regulating their smartphones used in classrooms [20]

In writing, Wali and Omaid [21] found that SMS (Short Messaging Service) negatively impacts students' writing skills. While the study did not elaborate on how SMS affects students' writing skills, it can be speculated that it is due to the nature of the messaging where faulty English sentence construction and spelling mistakes are widely accepted. Green [22] carried out a survey and interviewed students concerning their practices of smartphone use in writing classrooms. Based on his report, smartphone use facilitates students' access to course materials, gains more information about the assigned topics of discussion, and takes notes of the lecture. However, the device could be a source of distraction when teachers failed to make the lesson interesting for the students. Dietz and Henrich [23] found that students who texted or received messages 
during lectures had lower performance scores than students with no exposure to text messages.

In the university classroom, Langmia and Glass [24] showed one of the significant findings in their study that those who have been in the university longer had a stricter policy when dealing with smartphones in the classroom than lecturers at the university less than five years. The newest faculty members are not tolerant of smartphones, similar to senior professors. Most lecturers maintain the stricter policy in their syllabi in dealing with smartphone use in the classroom. Other faculty members suggested different measures such as banning smartphones completely, tolerate the vibrate features only, allow some time during the lecture for internet word search, which is imposed by individual choices and preferences. Langmia and Glass' [24] research showed conflicting approaches by faculty on how to deal with smartphone use in the classroom. Some faculty members use smartphones for pedagogic reasons and experience positive results with little success. Thus, they conclude that a university social media tolerant policy for everyone to abide by in the $21^{\text {st }}$ century seems to be the solution to smartphone use in the classroom.

Academics suggested the use of self-regulation, which is defined as the individual's ability to focus on predetermined goals despite distractors [25] [26] [27] [28] [29]. Previous literature explored students' self-regulation in dealing smart phones use during lecture time [30]. When self-regulated, specific students noted the following - no problem concentrating in class, not easily distracted, no problem going back to the topic quickly, controlling feelings, staying focused on the goal, and not allowing anything to distract personal plan of action.

\section{$3 \quad$ Methodology}

This study addresses the role of smartphones in an academic writing course. In the teacher-researchers' classes, students were allowed to use their smartphones as they see fit. Toward the end of the 16-week semester, students were asked to write reflective writings concerning their use of smartphones during their writing class.

\subsection{Participants}

The students $(n=50)$ were enrolled in an elective course, Academic Writing 1 . The students came from different backgrounds $-3^{\text {rd }}$ and $4^{\text {th }}$ years and are enrolled in Thai (the Thai language is the medium of instruction) and International (English is the medium of instruction) programs. Some students had not taken any writing courses before taking this course, especially those who came from the Thai program.

\subsection{The writing course}

The writing course has the following outcomes: to know the process of writing, to write a clear, well-structured essay, and to work collaboratively and apply skills learned 
in the writing course. Students were asked to work in groups to produce two essays, including outlines.

\subsection{Reflective writings}

With a vast number of quantitative research studies on smartphone use in the classroom, this study considered a qualitative approach to gathering and analyzing the data. This approach aims to understand the data from the students' perspectives [31]. By asking the students to write freely about the use of smartphones in their writing course, they are expected to share their deeper insights about the query sought to be answered in the current study.

\subsection{Data collection and analysis}

During the writing course, the teacher-researchers decided to let the students use their smartphones freely without interventions. However, the teacher-researchers would write on the board to remind everyone to use their smartphones wisely and correctly during class hours. The purpose was to allow the students to be responsible for their actions and find out at the end of the semester what the students think and how they feel for giving them the freedom to use their mobile devices during class. At the end of the semester, the researchers asked them to write their reflections using a Google form.

The data analysis utilized inductive coding. The initial codes were given to a colleague for inter-rater agreement, which resulted in $92 \%$, an acceptable agreement rating between two raters. Unclear codes were revised accordingly.

\section{$4 \quad$ Findings}

In table 1, seven specific functions were coded as the facilitative role of smartphones. The first is the resource-based function, as it focuses on finding information. Specifically for writing, it is used as a resource to find a piece of extra information for an essay and lookup sources, references, or evidence for writing. Another function emphasizes on cognitive aspect - knowing the meaning of words by using online translation services. Smartphones also pave the way for enhancing memory as the students can use them to take notes (i.e., taking photos of slides) and use them to review the lesson (i.e., replaying a recorded lesson). For output-based function, the students use the smartphone to do tasks assigned in class. Concerning collaborative-based function, they use it to prepare group tasks. For entertainment, it is used for relaxation purposes. In the communication function, it is utilized to connect with friends and family. 
Table 1. Facilitative role of smartphones

\begin{tabular}{|l|l|}
\hline \multicolumn{1}{|c|}{ Code } & \multicolumn{1}{|c|}{ Sample statement } \\
\hline Resource-based function & $\begin{array}{l}\text { Look up information quickly; f indextra information for the essay; } \\
\text { lookupfor sources, references ,or evidence for writing; Find more } \\
\text { information about the lesson; search for more information; s earching } \\
\text { for something related to theclass'lesson }\end{array}$ \\
\hline Cognitive-based function & $\begin{array}{l}\text { Finding vocabulary meaning; finding translation words in lessons; us- } \\
\text { ing Google translate; look for the meaning of words and grammar use; } \\
\text { search for the Thai meaning of the word; translate unknown words; use } \\
\text { the dictionary app }\end{array}$ \\
\hline Memory-based function & $\begin{array}{l}\text { Take pictures from the slides when needed; taking photos of the vital } \\
\text { content taught by teachers; use for taking short note; use to take notes } \\
\text { because it's faster than writing in my notebook; use to preview video- } \\
\text { related learning content }\end{array}$ \\
\hline Output-based function & $\begin{array}{l}\text { When the teacher asks students to read the essay, articles or do assign- } \\
\text { ment in class; when we play Kahoot; preparing for a short presentation } \\
\text { and finding words }\end{array}$ \\
\hline Collaborative-based function & $\begin{array}{l}\text { When preparing a group presentation; when students have to do the as- } \\
\text { signment in class or group work; when brainstorming about a scientific } \\
\text { topic }\end{array}$ \\
\hline Entertainment-based function & $\begin{array}{l}\text { Use during break time and when you have nothing to do } \\
\text { It gives peace of mind } \\
\text { Being in touch with social updates }\end{array}$ \\
\hline Communicative-based function & Family and friends who need to reach you right away \\
\hline
\end{tabular}

In the excerpts below, Somchai, Nok, Namwan, and Non affirmed smartphone use's facilitative role and functions in the classroom. Somchai talked about the use of a dictionary (resource-based), finding information (resource-based), and taking photos (memory-based). Nok and Namwan underscored its use for output-based (i.e., playing Kahoot). And Non insinuated its use as a tool to collaborate with others to do various activities (collaborative-based).

Somchai: There is no need of using a phone in a class; however, it does give benefits having it from time to time, like when you want to use the dictionary, find some related topics lecturers are talking about, or even when you forget your textbook you can rely on your phone to take a picture of the page lecturers want you to read.

Nok: Search vocabulary in class, such as writing an email. I don't to some words so I have to search google translate or dictionary. Cooperate with various activities, such as teachers, to play games about learning content. And not using a mobile phone while the teacher is teaching.

Namwan: When I don't know vocabulary mean, I go on dictionaries app on my phone and find meaning of that vocabulary. When in the class has some quiz (Kahoot).

Nom: Students can search the resources from the internet or use translates online. It's convenient for student to translate the vocabulary without taking a large dictionary.

Table 2 underscores the debilitative role of smartphones with four functions. First, it is the source of lacking focus when studying. As a result, it is a source of lacking comprehensibility. Also, it is a source for lacking concentration and for distracting others in the classroom. 
Table 2. Debilitative role of smartphones

\begin{tabular}{|l|c|}
\hline \multicolumn{1}{|c}{ Code } & Sample statements \\
\hline \multirow{4}{*}{ Cognitive distraction } & Don't focus on what we study \\
\cline { 2 - 2 } & Don't concentratewhen studying \\
\cline { 2 - 2 } Undesirable behaviors & Not understand the lesson \\
\cline { 2 - 2 } & Use for other objective that is out of the classroom lesson \\
& Ignore study \\
\cline { 2 - 2 } & Playing games and on social media while studying \\
\cline { 2 - 2 } & Distract the class \\
\cline { 2 - 2 } & Calling is disturbing \\
\cline { 2 - 2 } & Disturb others \\
\cline { 2 - 2 } & Disturb learning time \\
\cline { 2 - 2 } & Kindof annoying when it makes sound or vibration \\
\hline
\end{tabular}

In the excerpts below, Ton and Boom cautioned about not using smartphones in class. It could lead to lack of focus and concentration, resulting in difficulties in understanding the lesson (see Cognitive distraction). Moreover, it could result in undesirable behaviors in learning.

Ton: Because of everybody has internet on mobile phone sometimes it make student don't pay attention to study because they play game, surfing on FB, Twitter or another online application.

Boom: While teacher teaching or if it doesn't relate to the lesson, you should not use mobile phone.

Some insinuations (see excerpts below) are related to self-regulation strategies, recognizing the debilitative nature of smartphone use in the classroom. Tam suggested students limit smartphone usage when the teacher is teaching or when the students have difficulty in comprehending the lesson. Meanwhile, Peem recommended its use at the right time.

Tam: During important parts of the lessons, mobile phone use should be limited (Students should be reminded by the teacher not to use mobile phones).

Peem: In case of lecturing, while you are needed to concentrate to the class, when class is so intense and essential, you should not pick your mobile phone if it is not a proper time.

\section{$5 \quad$ Discussion and conclusion}

The present study highlighted the facilitative and debilitative roles of smartphone use in an academic writing course. The facilitative role is similar to previous studies [1] [2] [3] [4] [5] [9] [11]. Its functions as sources of distraction and undesirable behavior are similar to Green's study [22].

Despite the debilitative role, we have found using smartphones in class has facilitative functions as resource-based, cognitive-based, memory-based, output-based, collaborative-based, entertainment-based, and communicative-based. We believe that incorporating smartphones and other devices into our writing class is beneficial to our students' learning. As Sharples [25] suggested, rather than seeing mobile devices as 
disruptive, educators should seek to exploit the potential of technologies and find ways to put them into good use to benefit learning practice. Smartphone use in a writing class has various facilitative roles, and that it helps to learn as a whole. The findings cater the affordances to today's world of technology, where learners have comprehensive access to most of the technology that they can use as learning tools. The positivity of smartphone use in this writing course parallels some scholars who believed that mobile devices or smartphones make learners more creative, increase communication, collaborate with teachers and other students, increase their technology skills, and improve their learning in general [17].

While the findings concerning the roles of smartphone use in the writing course are not new, some thoughts on self-regulation of smartphone use are novel (see excerpts from Tam and Peem). Tam, for example, implied that its use should be limited. Additionally, teacher control is needed. Peem underscored the importance of using the smartphone properly. With students' insights, there is a need to promote self-regulation of smartphone use in the classroom. Accordingly, a self-regulated student knows the limitations of smartphone use in class. Future studies may determine self-regulation strategies of smartphone use during in-class or out-of-class writing activities.

\subsection{Self-regulation strategies on smartphone use}

Hence the advantages of smartphone use in writing cannot be denied; the following strategies in regulating its use in the classroom are recommended. This study's strategies include requesting students to be mindful of others and asking them to write guided reflections.

To avoid distracting the class, one has to be mindful of others. When students are aware that a beep or vibration of their phone could distract the whole class, they may have to put their phones in silent mode. They can still use it for various functions such as resource, cognitive, memory, etcetera. As Tam suggested, the teacher may have to remind students about regulating their phone use in the classroom.

Students may also be asked to write a guided reflection concerning their use of smartphones in class. In the guided reflection, students may have to think of some situations where smartphones are helpful to them and those around their circle. Not only that, they have to think of situations where their use of smartphones 'went wrong' - for example, the beeping of the phone. Herein, they could be asked to consider the feelings of those around them and think of ways on how to make sure that 'beeping of the phone' would not happen again.

\subsection{Implications for teaching}

Smartphones could help student learning, and it holds immense potential in improving their writing skill. It helps facilitate a change from traditional pedagogies to a more technology-enhanced pedagogy in writing. However, teachers could ascertain how helpful a pedagogy against others by doing, for example, classroom research. Teachers should be encouraged to let students utilize affordances they have these days. In light 
of its debilitative functions, negotiation between teachers and students also plays a vital role in using smartphones to avoid unnecessary distractions and undesirable behaviors.

\section{References}

[1] Bachore, M. M. (2015). Language learning through mobile technologies: An opportunity for language learners and teachers. Journal of Education and Practice, 6, 50-53.

[2] Darmi, R., \& Albion, P. (2014). A review of integrating mobile phones for language learning. Proceedings of the 10th International Conference Mobile Learning, 93-100.

[3] Hossain, M.E., \& Ahmed, S.M.Z. (2016). Academic use of smartphones by university students: a developing country perspective. Information Science \& Library Science, 34(4), 651665, https://doi.org/10.1108/el-07-2015-0112

Wechsumangkalo, S. (2018). Thai University Student's Perceptions and Practices of Smartphone Use for English Language Learning. Proceedings of the Asian Conference on Education. http://papers.iafor.org/wp-content/uploads/papers/ace2018/ACE2018_43498.pdf

[5] Yedla, S. (2013). MALL (Mobile Assisted Language Learning): A paradise for English language learners. IJ-ETS International Journal of English Language \& Translation Studies, 1(2), 91-99.

[6] Solihati, N., \& Mulyono, H. (2018). Designing and Evaluating the Use of Smartphones to Facilitate Online Testing in Second-Language Teacher Education (SLTE): An Auto-Ethnographic Study. International Journal Of Emerging Technologies In Learning (IJET), 13(01), pp. 124-137. http://dx.doi.org/10.3991/ijet.v13i01.7683

[7] Kukulsa-Hulme, A (2017). Mobile Usability in Educational Contexts: What have we learnt. International Review of Research in Open and Distance Learning, 8(2), 1-16, https://doi.org/ 10.19173/irrodl.v8i2.356

[8] Kukulsa-Hulme, A. \& Shield, L. (2008). An Overview of Mobile Assisted Learning: From Content Delivery to Supported Collaboration and Interaction. ReCall, 20(3), 271-289. https://doi.org/10.1017/s0958344008000335

[9] Kim, I., Jung, G., Jung, H., Ko, M., Lee, U., (2017). Let's FOCUS Mitigating Mobile Phone Use in College Classroom. Proceedings of ACM on Interactive Mobile, Wearable, and Ubiquitous Technologies. 1(3), 1-29, https://doi.org/10.1145/3130928

[10] Tayebinik, M. \& Puteh, M. (2012). Mobile Learning to Support Teaching English as a Second Language. Journal and Education and Practice 3, 56-63.

[11] Roschelle J., \& Pea, R. (2002). A Walk on the WILD side: How wireless handhelds may change CSCL. Retrieved Ir January $r \cdot r \cdot$ from http://ctl.sri.com/publications/downloads/WalkWildSide.pdf, https://doi.org/10.3115/1658616.1658624

[12] Squire, K., Jan, M., \& Mathews, J. (2007). The design and use of simulation computer games in education. In B.E. Shelton and D.A. Wiley (eds.), The design and use of simulation computer games in education (pp. 264-296). Rotterdam, the Netherlands: Sense Publishers, https://doi.org/10.1163/9789087903121

[13] Squire, K., \& Dikkers, S. (2012). Amplifications of learning: Use of mobile media devices among youth. Convergence: The International Journal of Research into New Media Technologies, 18(4), 445-464, https://doi.org/10.1177/1354856511429646

[14] Yancey, Kathleen B. (2009). 2008 NCTE presidential address: The impulse to compose and the age of composition. Research in the Teaching of English, 43(3), 2008.

[15] Wali, A. Z., Popal, A. W (2020). The emerging issues and impacts of technology in classroom learning. International Journal of Emerging Technologies in Learning, 15(15), 237245, https://doi.org/10.3991/ijet.v15i15.14175 
[16] Thomas, K., \& Muñoz, M. A. (2016). Hold the phone! High school students' perceptions of mobile phone integration in the classroom. American Secondary Education, 44(3), 19-37.

[17] West, M., \& Voslo, S. (2013). Policy Guidelines for Mobile Learning. Retrieved 1 August 2020 from https://www.researchgate.net/publication/258211567

[18] Beland, L. P., \& Murphy, R. (2015). In brief... Phone home: Should mobiles be banned in schools? CenterPiece Summer 2015, 10-11.

[19] McCoy, B.R. (2016). Digital distractions in the classroom phase II: Student classroom use of digital devices for non-class related purposes. Faculty Publications, College of Journalism \& Mass Communications. Paper 90, 1-43.

[20] Inyeop Kim, Gyuwon Jung, Hayoung Jung, Minsam Ko, Uichin Lee. 2017. Let's FOCUS: Mitigating Mobile Phone Use in College Classrooms. ACM on Interactive, Mobile, Wearable and Ubiquitous Technologies, Vol. 1. No. 3, Article 63. Tananuraksakul, N. (2015). The effect of online dictionaries usage on EFL undergraduate students' autonomy. Teaching English with Technology, 15(4), 3-15. Beland, L.P., \& Murphy, R. (2015). In brief... Phone home: should mobiles be banned in schools? CenterPiece Summer 2015, 10-11, https://doi. org $/ 10.1145 / 3130928$

[21] Wali, A. Z., \& Omaid, M. E. (2020). The use of smartphones as an educational tool in the classroom: Lecturers' perceptions. International Journal of Emerging Technologies in Learning, 15(16), 238-247, https://doi.org/10.3991/ijet.v15i16.14179

[22] Green, M. (2019). Smartphones, distraction narratives, and flexible pedagogies: Students' mobile technology practices in networked writing classrooms. Computers and Composition, 52, 91-106, https://doi.org/10.1016/j.compcom.2019.01.009

[23] Dietz, S., \& Henrich, C.. (2014). Texting as a distraction to learning in college students. Computers in Human Behavior, 36,163-167, https://doi.org/10.1016/j.chb.2014.03.045

[24] Langmia \& Glass (2014). Coping with Smart Phone 'Distractions' in College Classroom. Teaching Journalism and Mass Communication, 4(1), 13-23.

[25] Sharples, M (2003). Disruptive devices: mobile technology for conversational learning. International Journal of Continuing Engineering Education and Lifelong Learning, 12(5/6): 504-520, https://doi.org/10.1504/ijceell.2002.002148

[26] Corno, L. (1993). The best-laid plans modern conceptions of volition and educational research. Educational Researcher, 22(2), 14e22, https://doi.org/10.3102/0013189x022002014

[27] Karoly, P. (1993). Mechanisms of self-regulation: a systems view. Annual Review of Psychology, 44(1) 23e52.

[28] Kuhl, J. (1992). A theory of self-regulation: action versus state orientation, selfdiscrimination and some applications. Applied Psychology, 41(2), 97e129, https://doi.org/10.1111/ j.1464-0597.1992.tb00688.x

[29] Zimmerman, B. J. (2000). Attaining self-regulation: a social cognitive perspective. In M. Boekaerts, P. R. Pintrich, \& M. Zeidner (Eds.), Handbook of self-regulation (pp. 13e39). Burlington: Elsevier Academic Press, https://doi.org/10.1016/b978-012109890-2/50052-4

[30] Gokçearslan, S. Mumcu, F K. Haslaman, Cevik, Y D. (2016). Modelling smartphone addiction: The role of smartphone usage, self-regulation, general self-efficacy, and cyberloafing in university students. In Computers of Human Behavior, 63: 639-649, https://doi.org/ 10.1016/j.chb.2016.05.091

[31] Seliger, H. W., \& Shohamy, E. (1989). Second language research methods. Oxford: Blackwell. 


\section{Authors}

Jeffrey Dawala Wilang hails from Dilong, Tubo, Abra. He currently lectures at the School of Foreign Languages, Institute of Social Technology, Suranaree University of Technology, Nakhon Ratchasima, Thailand. His research interests are psycholinguistics and English as a lingua franca.

Michelle Andrino Garcia is a full-time lecturer in the School of Liberal Arts, Department of Language Studies, King Mongkut's University of Technology Thonburi. Her research interests are teaching and learning strategies, global Englishes and languaging.

Article submitted 2021-05-13. Resubmitted 2021-06-20. Final acceptance 2021-06-22. Final version published as submitted by the authors. 